\title{
INFLUENCE OF CLIMATIC VARIABLES ON CROWN CONDITION IN PINE FORESTS OF NORTHERN SPAIN
}

\author{
SANZ-ROS, A.V. ${ }^{1}$; PAJARES, J. ${ }^{1}$, DÍEZ, J.J. ${ }^{1}$
}

1. Plant Production and Forest Resources Department. University of Valladolid. Avenida de Madrid 44, 34004 Palencia. Spain. tonisanz@pvs.uva.es.

Sanz-Ros, AV, Pajares, JA, Diez, JJ (2008) Influence of climatic variables on crown condition in pine forest of northern Spain. In: Bravo, F, LeMay, V, Jandl, R, Gadow, KV (Eds.) Managing Forest Ecosystems: The Challenge of Climate Change. Springer, Netherlands, pp. 103-115. ISBN 978-1-4020-8432-6.

\section{INTRODUCTION}

Climate Change over the last century has created concern to the scientific community, as it could have a major impact on natural and social systems at local, regional and national scales Current mitigation policies derived from Kyoto Protocol are following two main ways: reduction of gas emissions, and implementation of a sustainable development assuring persistence of greenhouse carbon sinks, mainly forests lands.

Sustainable forest management is an essential tool to assure the permanence of our forests and to maintain properly their ecological functioning. Some sustainable models proposed that terrestrial ecosystems together with bioenergy systems, including capturing and storing carbon, may even neutralize unsustainable historical carbon emissions in the course of a century (Obersteiner, M., Azar, Ch., Kauppi, P., Möllersten, K., Moreira, J., Nilsson, S., Read, P.., Riahi, K., Schlamadinger, B., Yamagata, Y., Yan, J. and van Ypersele, J.P., 2001). They can offer a permanent carbon sink by the technological option of capturing carbon from biomass conversion facilities (Kraxner, F., Nilson, S., Obersteiner, M., 2003). But the role of forest as a $\mathrm{CO} 2$ sink could be influenced by the occurrence of forest pests and diseases, causing tree defoliation and canopy reduction. Climatic factors could influence crown condition, question that is tried to answer with this work.

Crown condition is closely related to forest condition, and also, the contribution of each individual tree to $\mathrm{CO} 2$ sequestration depends on its crown development. Visual assessment of defoliation became accepted as the standard method for largescale intensive monitoring of forest condition in Europe, and it has been systematically assessed since 1986 throughout the whole Europe (EC and UN/ECE, 2000).

Estimation of crown density (or crown transparency), method, described by Innes (1990), and harmonized (Innes, 1993) using guidelines proposed by ICP Forests (1992), has been widely used as an indicator of the vitality of forest trees and of the degree of damage (Zierl, 2002). Canopy transparency (CT) concept is wider than defoliation, because it takes into consideration factors like unusual reduction of leaf size, presence of flowers and cones, branching deformation or shoot death, and 


\section{SANZ-ROS, A.V.; PAJARES, J., DÍEZ, J.J.}

also premature needle loss (Ferretti, 1994), so that defoliation is included in this term. There are several causes of premature needle loss, sometimes they are well known (pests and diseases), but in many occasions they are far from clear, ranging from environmental stress (Zierl, 2004), such as low availability of water or extreme values of temperature, to other variables related to the management or disturbance events. Drought is a major factor in forest decline, making tree more vulnerable to fungi and pest attacks (Wellburn,1994; Klap, J.M. Oude Voshaar, J.H., de Vries, W., Erisman, J.W., 2000). In Mediterranean climate, growth of forest trees is subjected to many climatic constrains, particularly the availability of water (Gracia, C.A., Tello, E., Sabaté, S. Bellot, J., 1999). It is known that some climatic factors can influence crown condition, but it is not known how this influence is, and which are these climatic parameters for each region. It is expected that variation of the climatic factors would be different among the diverse regions in future climate change scenarios, so its needed to consider climate trends obtained by several surveys at different scales.

Some studies indicate that rainfall would have a general decrease in south Europe to the Mediterranean (Schönwiese and Rapp, 1997; Piervitali, E., Colacino, M., Conte, M 1., 1997; Buffoni, L., Maugeri, M., Nanni, T., 1999; Brunetti, M., Maugeri, M., Nanni, T., 2000, 2001). It seems that, in Spain, annual rainfall shows a trend towards a decrease over the whole Iberian Peninsula, the greatest decreases occurring in summer, but being the winters wetter (Karas, 1997; Esteban-Parra, M.J., Rodrigo, F.S., Castro-Díez, Y., 1998; Hulme and Sheard, 1999; Parry, 2000; IPCC, 2001; Mossman, 2002). In any case, some review showed an increased variability of precipitation everywhere (Dore, 2005). Temperature records show an increase in the global mean temperature between 0.4 and $0.8{ }^{\circ} \mathrm{C}$ along the $20^{\text {th }}$ century that cannot be attributed to the internal variability of the climate system (Panel on Reconciling Temperature Observations, 2000; Parry, 2000). Other studies showed a global warming rate of $0.3-0.6{ }^{\circ} \mathrm{C}$ since the $19^{\text {th }}$ century, due to either anthropogenic (IPCC, 2001) or to astronomic causes (Soon, W., Baliunas, S., Posmentier, E.S., Okeke, P., 2000; Landscheidt, 2000). In addition, some studies pointed to that the last decade (1990-1999) was the warmest record, both annually and for the winter season.

This increase in the global temperature is not homogeneously distributed on the earth surface, varying among the different regions and locations. According to this, climate models currently have predicted a temperature increase at different scales. The Third Assessment Report projections for the present century, on a global scale, are that average temperature rise by 2100 would be in the range of $1.4-5.8{ }^{\circ} \mathrm{C}$ (IPCC, 2001). Other models have forecasted approximately an increase of $1.5-3{ }^{\circ} \mathrm{C}$ up to the year 2100 in Europe (Kattenberg, 1996), or between $1-3.5^{\circ} \mathrm{C}$ for midlatitude regions (Watson, R.T., Zinyowera, M., Moss, R.H., Dokken, D.J., 1997). For the Iberian Peninsula, results seem to indicate an increase in the annual mean temperature of about $1.6^{\circ} \mathrm{C}$ over the last hundred years, with highest increases in summer (approximately $2^{\circ} \mathrm{C}$ ) and the lowest in winter (Hulme and Sheard, 1999; Parry, 2000). This change is also reflected in the behaviour of the extreme values, which showed significant trends in some regions of the globe, but not in others, where no significant changes were detected (DeGaetano, 1996; Heino, R., Brazdil, 


\section{INFLUENCE OF CLIMATIC VARIABLES ON CROWN CONDITION}

R., Forland, E., Tuomenvirta, H., Alexandersson, H., Beniston, M., Pfister, C., Rebetez, M., Rosenhagen, G., Rosner, S., Wibig, J.., 1999; Bonsal , B.R., Zhang, X., Vincent, L.A., Hogg, W.D., 2001). Previous analysis from various surveys showed that the behaviour of extreme temperatures and their associated impact strongly depended on local conditions.

In some respects, these climate changes are likely to act as an important driving force on natural systems (Parmesan and Yohe, 2003). The increase of temperature along the next 100 years would be equivalent to a poleward shift of the present geographic isotherms of approximately 150-155 km (Watson et al., 1997), causing changes in forest tree species distributions. Risk of pests and diseases will be increased due to this limits displacement, so that many species will be placed in an stressing environment. In this way, tree vigour of these species could decrease, leading to canopy decline manifested in symptoms as defoliation and discolouration.

The aim of this study was to find relationships between crown condition and some climatic parameters to identify which are those having a main influence on crown condition, and how this influence is shown in the tree (crown transparency), and to contribute to the understanding of how these parameters will affect under future climate change scenarios.

\section{MATERIALS AND METHODS}

In this study, 68 National Forest Inventory (NFI) plots were sampled from July to mid September of 2005. All plots were placed in a pilot zone in Palencia province (northwest of Spain, Figure 1), and were covered by three Pinus species (37 by $P$. sylvestris, 22 by $P$. nigra, and 9 by $P$. pinaster).

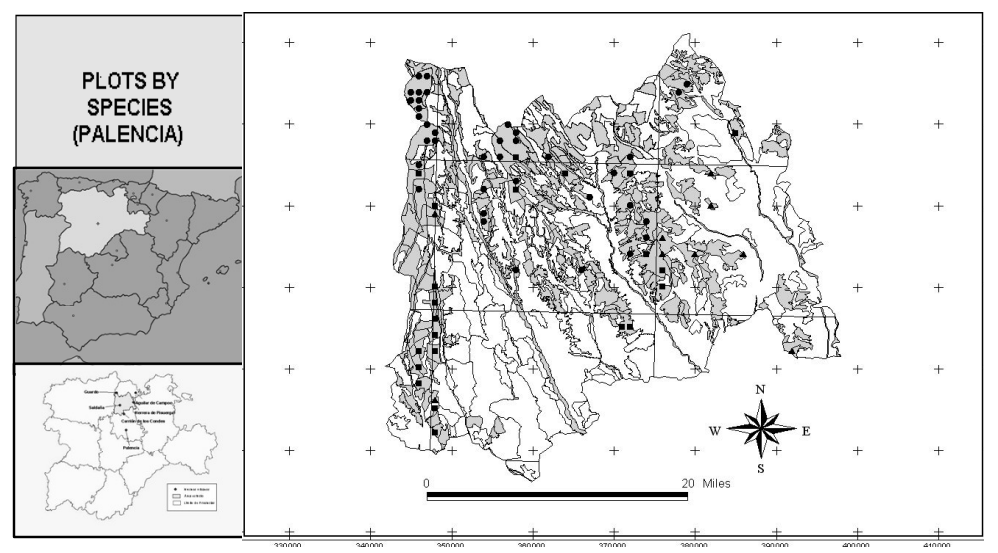

Figure 1: Distribution of plots in pilot zone in Palencia Province, Castilla y León, Spain. Plots were taken from a $2 \mathrm{~km}$ grid on tree covered area. Pinus sylvestris $(\bullet)$, Pinus pinaster $(\mathbf{\Delta})$, and P. nigra ( $\mathbf{\square})$.Gray surface is forest covered area. 


\section{SANZ-ROS, A.V.; PAJARES, J., DÍEZ, J.J.}

Most of the plots were pine plantations, in some cases mixed with different oak and pine species. This area is transitional between agricultural lands (southwards) and Cantabric mountains (northwards), and extends for 186642 ha, 60000 of them forested, showing enough climatic variations to study the influence of climatic factors in crown condition. This pilot zone is located between UTM coordinates $342.000,4.685 .000$, and 398.000, 4.741.000, ranging in altitude from 800 to 1000 m.a.s.l. (Figure 1). The climate is Mediterranean with a slight Atlantic influence: $11,49^{\circ} \mathrm{C}$ of mean temperature and annual rainfall of $519 \mathrm{~mm}$.

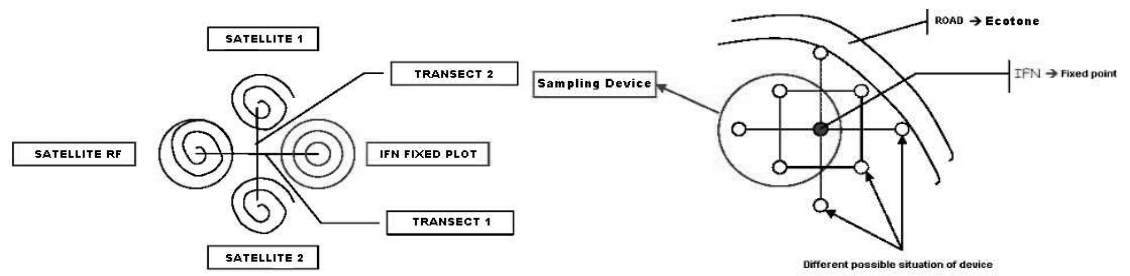

Figure 2: Sampling method with four subplots and two linear transects linking them (Left). IFN plot is a fixed plot, original transect orientation was $N-S$ and $E-W$, but it was able to be rotated in order to avoid roads or firewalls (Right).

Sampling method involved four subplots (Figure 2). One fixed subplot of $25 \mathrm{~m}$ radius (National Forest Inventory plot) and three subplot of $17.5 \mathrm{~m}$ radius, linked by two perpendicular linear transects of $50 \mathrm{~m}$. In each subplot, the 20 nearest trees in a spiral pattern were evaluated. Data showed for canopy transparency for each plot were means of 20 evaluated trees The establishment of one subplot in a road or firewall, where an edge effect is likely, was avoided by subplot rotation. However some other surveys have showed that there is no differences in defoliation between inside stand trees and edge trees (Durrant and Boswell, 2002).

Canopy transparency was estimated in the field according to the European Programme for the Intensive Monitoring of Forest Ecosystems, Level I (ICP forests, 1992). Crown density is a visual estimation of the amount of light passing through the tree crown relative to a reference tree with complete foliage. Canopy transparency is the opposite term, and is what was estimated in the present study comparing to reference pictures of canopy transparency for each species (Cadahia, D., Cobos, J.Mª., Soria, S., Clauser, F., Gellini, R., Grosoni, P., Ferreira, M.C.,1991; Ferretti, 1994). 


\section{INFLUENCE OF CLIMATIC VARIABLES ON CROWN CONDITION}

Table 1: Likely predictor climatic variables used to find correlations with plot canopy transparency.

\section{Annual December January February June July August}

\begin{tabular}{lccccccc}
\hline Mean Temperature & $\mathrm{x}$ & $\mathrm{x}$ & $\mathrm{x}$ & $\mathrm{x}$ & $\mathrm{x}$ & $\mathrm{x}$ & $\mathrm{x}$ \\
$\begin{array}{l}\text { Maximum } \\
\text { Temperature } \\
\begin{array}{l}\text { Minimum } \\
\text { Temperature }\end{array}\end{array}$ & $\mathrm{x}$ & $\mathrm{x}$ & $\mathrm{x}$ & $\mathrm{x}$ & $\mathrm{x}$ & $\mathrm{x}$ & $\mathrm{x}$ \\
Rainfall & $\mathrm{x}$ & $\mathrm{x}$ & $\mathrm{x}$ & $\mathrm{x}$ & & & \\
Solar Radiation & $\mathrm{x}$ & $\mathrm{x}$ & $\mathrm{x}$ & $\mathrm{x}$ & $\mathrm{x}$ & $\mathrm{x}$ & $\mathrm{x}$ \\
& $\mathrm{x}$ & & & & & & \\
\hline
\end{tabular}

Climatic long-term data for each plot were obtained from the Digital Climatic Atlas of Iberian Peninsula (Ninyerola M, Pons X y Roure JM, 2005), a recent climatic model in which it is used data from all the meteorological stations from pilot zone, 15 of them within and other 31 in nearby areas. Rainfall values are refereed to the last twenty years means, and temperatures to the last fifteen years before publishing the model.

Several climatic variables were chosen (Table 1) to study their possible relation to crown condition, including annual temperature means and monthly values of dry and cold seasons, its rainfall and solar radiation. All of these climatic variables were categorized in five homogeneous intervals (Table 2) with the aim of comparing plot canopy transparency among different levels of each climatic variable.

Plot canopy transparency values were transformed by decimal logarithm to obtain normal distribution and homocedasticity of data (Kolmogorov-Smirnov, Shapiro-Wilks and Bartlett tests). Analysis of Variance (ANOVA), with a signification level of 0.05 , was carried out to know if there were statistically significant differences in transparency values for the 68 sampled plots among the levels of rainfall, temperatures and solar radiation. Finally, the Bonferroni and Duncan test were used for multiple comparisons. To study the relationship between canopy transparency and climatic data, simple regression of untransformed data was used for each climatic variable, and multiple regression with backward selection was used with the aim of include several variables in the model to study cross effect among variables in crown transparency. 
SANZ-ROS, A.V.; PAJARES, J., DÍEZ, J.J.

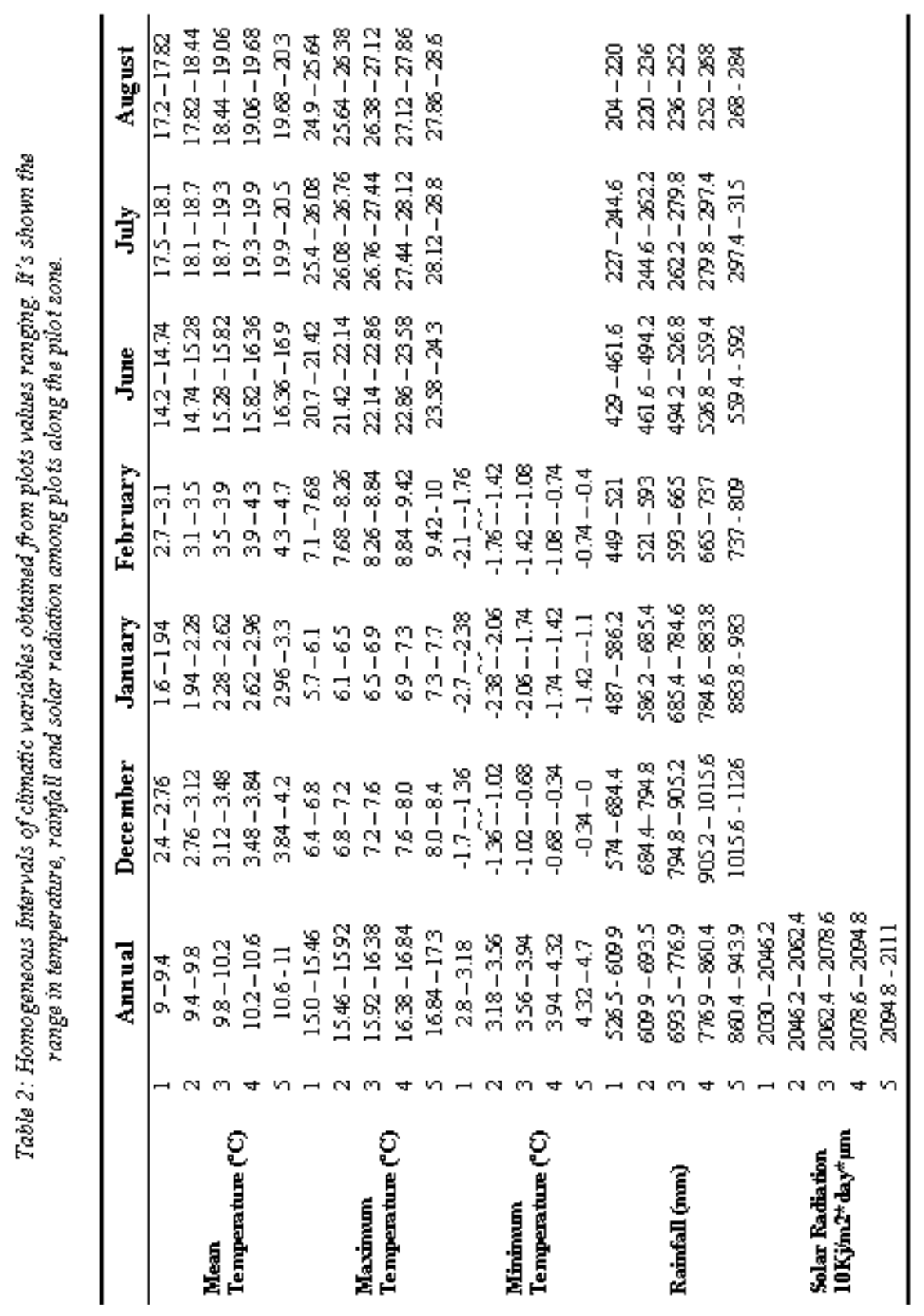




\section{INFLUENCE OF CLIMATIC VARIABLES ON CROWN CONDITION}

\section{RESULTS}

The Kolmogorov-Smirnov, Shapiro-Wilks and Bartlett tests proved normality and homocedasticity of the logarithm of mean plot canopy transparency (CT) data. The One Way ANOVA analysis showed that there were statistically significant differences between mean CT values of plots with different levels of July rainfall, Mean annual temperature and mean August temperature, whereas there were no significant differences in plot CT in relation with the other variables analysed, such as solar radiation, mean annual or minimum temperatures, annual or winter rainfall (table 3).

Table 3: Results of ANOVA between plot canopy transparency and 5 homogeneous levels of different climate variables.

\begin{tabular}{lccccccc}
\hline & Annual & December & January & February & June & July & August \\
\hline Mean Temp. & 4.200 & 2.231 & 1.535 & 1.873 & 2.106 & 1.282 & 2.736 \\
& $\mathbf{0 . 0 0 4} *$ & 0.076 & 0.203 & 0.126 & 0.090 & 0.286 & $\mathbf{0 . 0 3 6}$ \\
Max. Temp. & 2.318 & 1.492 & 2.029 & 2.275 & 1.345 & 1.466 & 2.281 \\
& 0.067 & 0.215 & 0.101 & 0.071 & 0.263 & 0.223 & 0.070 \\
Min. Temp. & 1.952 & 1.878 & 1.979 & 1.538 & & & \\
& 0.113 & 0.125 & 0.108 & 0.202 & & & \\
Rainfall & 2.049 & 2.297 & 1.236 & 1.010 & 1.536 & 2.758 & 1.519 \\
& 0.098 & 0.069 & 0.305 & 0.409 & 0.202 & $\mathbf{0 . 0 3 5 *} 0.207$ \\
Solar Rad. & 2.246 & & & & & & \\
\hline
\end{tabular}

* Number showed F value (up) and p-value (down). Numbers in bold refer to p-values lower than 0.05. f.d. $=67$ for all ANOVA.

* Abbreviations: Temp.$=$ temperature $;$ Max $=$ Maximum $;$ Min.$=$ Minimum $;$ Rad.$=$ Radiation.

In the analysis of rainfall, ANOVA showed significant differences in plot CT among different homogeneous levels of July rainfall (Figure 3, Top). Bonferroni test showed differences between levels 1 and 5 (Table 4), with a difference in precipitation of $60 \mathrm{~mm}$. The erratic behaviour of rainfall distribution (Dore, 2005) could preclude from making accurate predictions for the future. 
SANZ-ROS, A.V.; PAJARES, J., DÍEZ, J.J.

Table 4: ANOVA between logarithm of canopy transparency and 5 July rainfall levels (Up). There were significant $(p<0.05)$ differences between $C T$ in level 1 and 5 , as it is showed by Bonferroni multiple test (Down).

\begin{tabular}{cccc}
\hline & & & \\
July Rainfall & count & Mean & Homogeneous groups \\
\hline 1 & 13 & 1.27036 & $\mathbf{a}$ \\
2 & 15 & 1.29274 & $\mathbf{a b}$ \\
3 & 13 & 1.2988 & $\mathbf{a b}$ \\
4 & 13 & 1.31593 & $\mathbf{a b}$ \\
5 & 14 & 1.40098 & $\mathbf{b}$ \\
\hline
\end{tabular}

On the other hand, there were significant differences in plot CT among Mean annual temperature levels (Figure 3, Medium). Duncan multiple comparison test demonstrated significant differences $(\mathrm{p}<0.05)$ between CT in level 1 and 5 (Table 5), being their difference in temperature of $1.6^{\circ} \mathrm{C}$. If predictive models were accurate, this temperature increase, or even higher, could be reached in the next years.

Table 5: Bonferroni multiple test comparison demonstrated significant differences in pot canopy transparency between levels 1 and 5 of mean annual temperatures

\begin{tabular}{cccc}
\hline Mean annual Temperature & count & Mean & Homogeneous groups \\
\hline 1 & 13 & 1.23130 & $\mathbf{a}$ \\
2 & 17 & 1.28347 & $\mathbf{a b}$ \\
3 & 18 & 1.34915 & $\mathbf{b}$ \\
4 & 16 & 1.35964 & $\mathbf{b}$ \\
5 & 4 & 1.41152 & $\mathbf{b}$ \\
\hline
\end{tabular}

ANOVA results comparing canopy transparency among plots with different levels of Mean August temperature also showed significant $(\mathrm{p}<0.05)$ differences (Figure 3, Bottom). Bonferroni multiple comparison test revealed differences between levels 1 and 5 (Table 6), with a variation in August temperature of $2.48{ }^{\circ} \mathrm{C}$. The ANOVA analysis showed that there were no significant differences in CT values neither among levels of mean or minimum temperatures (annual, June, July, December, January and February) nor among different solar radiation or rainfall levels (annual, June, August, December, January and February).

Table 6: Tukey multiple comparison test, showing significant differences in plot canopy transparency between levels 1 and 5 of mean August temperatures.

\begin{tabular}{cccc}
\hline Mean August Temperature & count & Mean & Homogeneous groups \\
\hline 1 & 16 & 1.25000 & $\mathbf{a}$ \\
2 & 12 & 1.29750 & $\mathbf{a b}$ \\
3 & 14 & 1.31658 & $\mathbf{a b}$ \\
4 & 12 & 1.35859 & $\mathbf{a b}$ \\
5 & 14 & 1.37184 & $\mathbf{b}$ \\
\hline
\end{tabular}




\section{INFLUENCE OF CLIMATIC VARIABLES ON CROWN CONDITION}
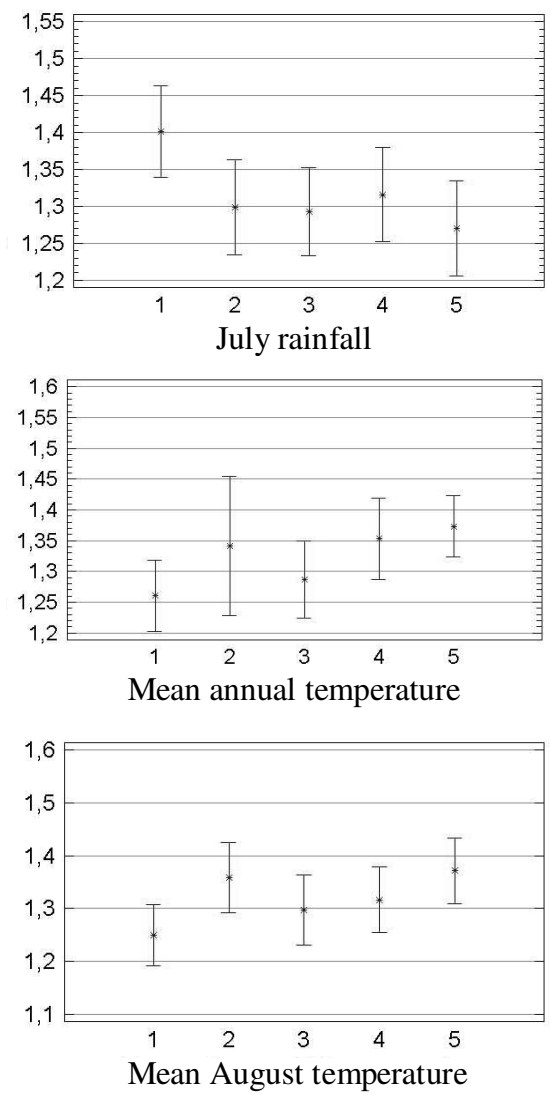

Figure 3: Confidence intervals of ANOVA analysis among the logarithm plot canopy transparency and July rainfall (Top), mean annual temperature (Medium), and mean August temperature levels (Bottom). Each variable was categorized in 5 homogeneous intervals.

To assess the influence of these parameters in plot canopy transparency, a simple regression was done for each of the significant parameters. The regression models for CT versus July rainfall, maximum temperature or August temperature were significant $(\mathrm{p}<0.05)$, with a negative slope for the precipitation model and positive for the temperature models. The $\mathrm{R}^{2}$ adj for these models was only $10.66 \%$ for July rainfall, $9.19 \%$ for Maximum temperature and $8.01 \%$ for August temperature (Figure 4), suggesting that canopy transparency was not only explained by climatic parameters, however there was an evident influence of these parameters on this transparency. 
SANZ-ROS, A.V.; PAJARES, J., DÍEZ, J.J.
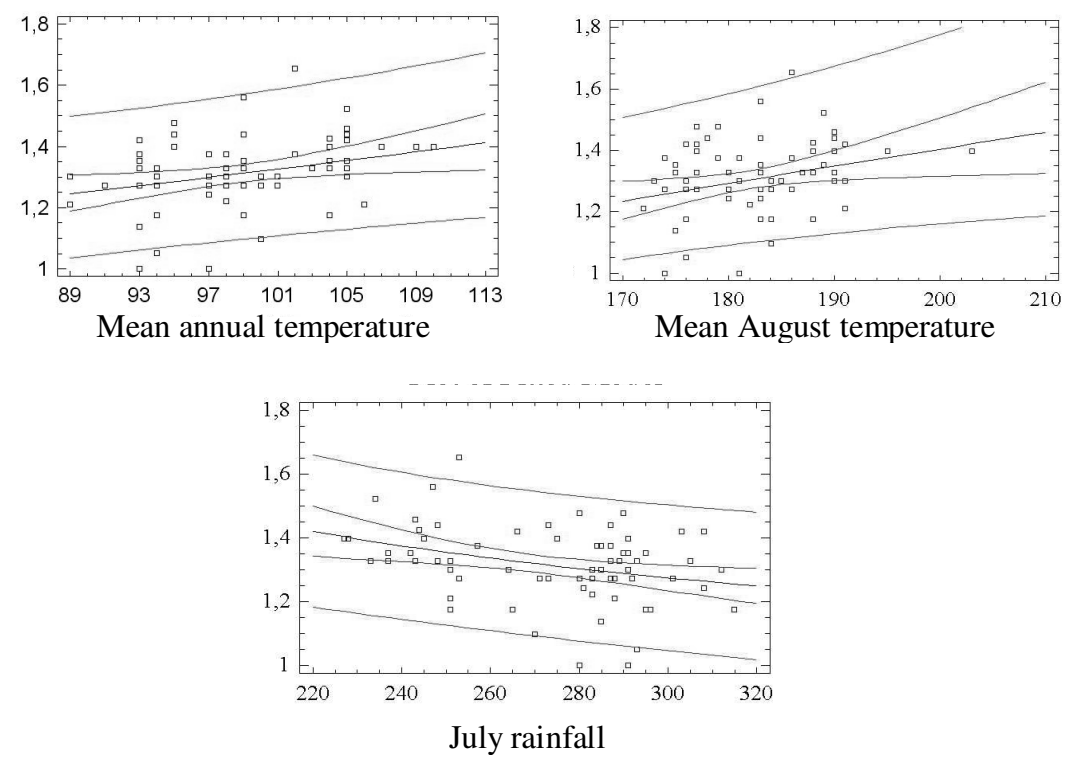

Figure 4: Regression models for canopy transparency and climatic parameters (mean annual and mean august temperatures and July rainfall). Reciprocal- $Y$ regression model related to maximum temperature [Plot CT $=1 /(1.42482-0.000412949 *$ Maximum temperature $)]$

(Left). Double reciprocal model related to mean August temperature [Plot CT $=1 / 0.155929$

+111.238 / August temperature] (Right). Reciprocal-X regression model related to July rainfall [Plot CT $=0.872209+120.684 /$ July rainfall] $($ Center $)$.

Multiple regression analysis with backward selection showed that July Rainfall was the variable with higher effect on canopy transparency. However, although the model is significant, $\mathrm{R}^{2}$ was quite low, with only $10.66 \%$. Multiple regression model obtained is not improving $\mathrm{R}^{2}$ of models with only one climatic variable.

\section{DISCUSSION}

\subsection{Current state.}

According to ANOVA results, a negative deviation in July rainfall (60 mm) led to a significant increase of CT (about $10 \%$ ). Precipitation started to decrease in June, but temperatures remained at moderate levels. In July temperatures were higher but rainfall was much lower, so the combination of drought and high temperatures creates an stressful environment, causing the decrease of tree vigour. Thus, July rainfall may act as a key factor to tree condition in Castile and Leon pine forests, mainly regarding tree vigour and resistance to pest and disease. In this sense, July is not a suitable month for some management practices, as thinning and pruning in the 


\section{INFLUENCE OF CLIMATIC VARIABLES ON CROWN CONDITION}

pine forests of Castile and Leon, since the risk of insects attack will increase with the decreasing of tree vigour.

On the other hand, mean temperatures also influenced CT. As it was showed by the ANOVA analysis, an increase on this parameter $\left(0,4{ }^{\circ} \mathrm{C}\right)$ caused a significant increase in plot CT (6\%), and an increase of $1,6^{\circ} \mathrm{C}$ (between levels 1 and 5) caused a CT increase of $9 \%$, and it is just the increase of temperatures in the Iberian Peninsula over the last hundred years (Hulme and Sheard, 1999). Plots with higher mean temperatures reached higher CT values, mainly when rainfall decrease was more acute. In addition, mean August temperature also was influencing canopy, as there was an increase in CT (about $6 \%$ ) when august temperature increased $2.48{ }^{\circ} \mathrm{C}$. After the drought of July, August rainfall remained very low, and its high temperature could have enhanced the effect of dry conditions, leading to a decrease of tree vigour.

Also, these variations in climatic factors may affect forest pathogens, mainly to their sporulation and colonization success, since these are influenced by changes in temperature, precipitation, soil moisture and relative humidity (Brasier, 1996; Lonsdale and Gibbs, 1996; Houston, 1998).

A pattern in temperature and precipitation was observed in relation to plot $\mathrm{CT}$ in the pilot zone. Thus, most of plots that were placed in warmer and drier conditions showed higher CT values, and those that were sited in colder and wetter places showed lower CT values. This agrees with results of the Programme for the Intensive Monitoring of Forest Ecosystems in Europe, that showed that between 30-50\% of the variation in defoliation could be explained by the variation in stand age, soil type, precipitation, $\mathrm{N}$ and $\mathrm{S}$ deposition and foliar chemistry, for pine, oak and beech. For Scots pine, only age, precipitation and foliar Nitrogen content showed a significant relationship with defoliation, and a model with these predictor variables fitted $21 \%$ $\left(\mathrm{R}_{\text {adj }}^{2}\right.$ ) (De Vries, W., Vel, E., Reinds, G.J., Deelstra, H., Klap, J.M., Leeters, E.E.J.M., Hendriks, C.M.A., Kerkvoorden, M., Landmann, G., Herkendell, J., Haussmann, T., Erisman, J.W , 2003). The main achievement of our study is the identification of mean annual and mean August temperatures as important factors affecting crown condition of pine species. It becomes clear that there are many biotic and abiotic factors affecting canopy, and meteorological factors are just a small part of them, but these factors must be included in any predictive model for forest condition.

Part of the low $\mathrm{R}_{\text {ad }}^{2}$ values from regression models could be derived from to the subjectivity of visual crown assessment. Thus, more reliable methods should be developed for crown assessment. Indirect measures such as hemispheric photography are becoming increasingly more important (Kucharik, C.J., Norman, J.M., Gower, S.T., 1998).

Results obtained from this study suggest that canopy transparency is influenced by temperatures and precipitations of long term preceding years, not only by recent years conditions, as it is usually thought. Historical climatic conditions may influence the present crown condition, which is a result both of recent climatic conditions and past conditions.

Although the influence of these climatic variables on canopy transparency is demonstrated, other kind of variables must be included with the aim of predicting 
SANZ-ROS, A.V.; PAJARES, J., DÍEZ, J.J.

transparency for a particular site, such as silvicultural, structural or nutritional variables. Even other factors, such as the presence of pest and diseases should be required.

\subsection{Climate change scenarios}

Climatic trends point to a likely temperature increase in south-eastern Europe of about 1-3 ${ }^{\circ} \mathrm{C}$ (Kattenberg, 1996; Watson et al., 1997), and of $2^{\circ} \mathrm{C}$ in Spain, particularly during summer (Hulme and Sheard, 1999; Parry, 2000). Therefore, canopy transparency will follow the temperature increasing trend, causing a reduction of tree vigour, and leading to an increase of pests and diseases attack risk. If there is a $3{ }^{\circ} \mathrm{C}$ increase in temperature values, canopy transparency could increase about $18 \%$, which may represent an important reduction of canopy density. In addition, mean temperatures will probably increase due to climate change, a trend already detected in the last years in Spain (Del Río, S., Penas, A., Fraile, R., 2004), so an increase of transparency is expected also. This rise in maximum temperatures may cause physiologic effects in trees, having a negative impact on primary processes as photosynthesis and causing the increase of respiration rates (Boonen, C., Samson, R., Janssens, K., Pien, H., Lemeur, R., Berckmans, D., 2002).

In addition, rainfall will be more erratic (Dore, 2005) with a decreasing trend in Spain (Schönwiese, 1997), so it is likely that canopy transparency rates become higher due to this decrease. In Mediterranean ecosystems, summer is a marked dry season, and at the end of the summer there is a notable reduction in the canopy. Other studies also have revealed minimum canopy cover values during summer and autumn in pine plantations (Bryant, M.L., Bhat, S., Jacobs, J.M., 2005). Thus, it is advisable that crown assessment should be done during this period (augustSeptember), so that canopy reduction as a result of summer drought and high temperatures will be recorded.

Forest managers must notice these trends and adapt forestry practices with the aim of minimize this defoliation effect and contribute to forest sustainability. Further surveys are required to predict defoliation values for a particular site, considering that many other kind of variables are needed for a multivariate analysis of crown condition, that would explain, which are the main factors involved in this process.

These surveys will be useful to help forest managers to minimize defoliation and to ensure the permanence of our forests in a good condition, thus helping to mitigate climate change effects over the atmosphere.

\section{ACKNOWLEDGEMENTS}

Financial support of this study was provided by European Union, from the INTERREG IIIB Program, Atlantic area, exactly FORSEE Project. Thanks to Christophe Orazio for help us to obtain the climatic data and for trust us to carry out this project. 


\section{INFLUENCE OF CLIMATIC VARIABLES ON CROWN CONDITION}

\section{REFERENCES}

Brasier, C.M. (1996). Phytophtora cinnamomi and oak decline in southern Europe: Environmental constraints including climate change. Ann Sci For; 347-358.

Bonsal , B.R., Zhang, X., Vincent, L.A., Hogg, W.D. (2001). Characteristics of daily and extreme temperatures over Canada. Journal of Climate 14, 1959-1976.

Boonen, C., Samson, R., Janssens, K., Pien, H., Lemeur, R., Berckmans, D. (2002). Scaling the spatial distribution of photosynthesis from leaf to canopy in a plant growth chamber. Ecological Modelling $156,201-212$

Brunetti, M., Maugeri, M., Nanni, T (2000). Variations of temperature and precipitation in Italy from 1866 to 1995 . Theoretical \& Applied Climatology. 65, 165-174.

Brunetti, M., Maugeri, M., Nanni, T (2001). Changes in total precipitation, rainy days and extreme events in northeastern Italy. International Journal of Climatology. 21, 861-871.

Bryant, M.L., Bhat, S., Jacobs, J.M. (2005). Measurements and modelling of throughfall variability for five forest communities in the southeastern US. Journal of Hydrology 312, 95-108.

Buffoni, L., Maugeri, M., Nanni, T. (1999). Precipitation in Italy from 1833 to 1996. Theoretical \& Applied Climatology. 63, 33-40.

Cadahia, D., Cobos, J.Mª, Soria, S., Clauser, F., Gellini, R., Grosoni, P., Ferreira, M.C. (1991). Observación de daños en especies forestales mediterráneas. MAPA. Secretaría General Técnica, Madrid. Comisión de las Comunidades Europeas, Bruselas. ISBN: 84-7479-880-9, 96 pp.

DeGaetano, A.T. (1996). Recent Trends in Maximum and Minimum Temperature Threshold Exceedences in the Northeastern United States. Journal of Climate 9, 1646-1660.

Del Río, S., Penas, A., Fraile, R. (2004). Analysis of recent climatic variations in Castile and Leon (Spain). Atmospheric Research 73, 69-85.

De Vries, W., Vel, E., Reinds, G.J., Deelstra, H., Klap, J.M., Leeters, E.E.J.M., Hendriks, C.M.A., Kerkvoorden, M., Landmann, G., Herkendell, J., Haussmann, T., Erisman, J.W. (2003). Intensive monitoring of forest ecosystems in Europe:1. Objectives, set-up and evaluation strategy. Forest Ecology and Management 174, 7-95

Dore, M.H.I. (2005). Climate Change and changes in global precipitation patterns: What do we know?. Environment International, 31: 1167-1181.

Durrant, D., Boswell, R. (2002). Comparison of crown density assessments on trees within the stand and on ride edges within the forest. Forest Ecology and Management 157, 1-6

EC and UN/ECE.(2000). Forest condition in Europe. 2000. Executive report. UN/ECE and EC, Geneva, Brussels

Esteban-Parra, M.J., Rodrigo, F.S., Castro-Díez, Y. (1998) Spatial and temporal patterns of precipitation in Spain for the period 1880-1992. International Journal of Climatology. 18, 1557-1574.

Ferretti, M. (Ed.) (1994) Especies Forestales Mediterráneas: Guía para la evaluación de las copas. CECUN/ECE, Bruselas, Geneva.

Gracia, C.A., Tello, E., Sabaté, S. Bellot, J. (1999). GOTILWA: an integrated model of water dynamics and forest growth. In: Rodà, F., Retana, J., Gracia, C.A., Bellot, J. (Eds.), Ecology of Mediterranean Evergreen Oak Forests. Ecological studies, vol. 137. Springer Verlag, Berlin, Heidelberg, pp. 163 179.

Heino, R., Brazdil, R., Forland, E., Tuomenvirta, H., Alexandersson, H., Beniston, M., Pfister, C., Rebetez, M., Rosenhagen, G., Rosner, S., Wibig, J. (1999). Progress in the study of climate extremes in northern and central Europe. Climate Change 42, 151-181.

Houston, D.R. (1998). Beech bark disease. In: Britton, K. editor. Exotic pests of eastern forests. USDA Forest service, 29-41.

Hulme, M., Sheard, N. (1999). Escenarios de Cambio Climático para la Península Ibérica. Unidad de Investigación Climática, Reino Unido, P. 6.

ICP Forests (1992). Manual on Methodologies and Criteria for Harmonised sampling, Assessment, Monitoring and Analysis of the Effects of Air Pollution on Forests. Convention on Long-Range Transboundary Air Pollution, United Nations Environment Programme and United Nations Economic Commission for Europe, Geneva.

Innes, J.L. (1990). Assessment of Tree Condition. Forestry Commission Field Book 12. H.M.S.O., Londn, $96 \mathrm{pp}$.

Innes, J.L. (1993). Forest Health: its assessment and status. CAB International, Wallingford. 


\section{SANZ-ROS, A.V.; PAJARES, J., DÍEZ, J.J.}

IPCC (2001). Climate Change 2001: synthesis report. Contribution of Working Group I and III to the Third Assessment of the Intergovernmental Panel on Climate Change (IPCC). Cambridge University Press, Cambridge.

Kattenberg, A. et al. (1996). Climate models: Projections of future climate. In: Houghton, J.T., Meira Filho, L.G., Callander, B.A., Harris, N., Kattenberg, A., Maskell, K. (Eds.) Climate Change, 1995. The Science of Climate Change. Contribution of WG I to the $2^{\text {nd }}$ Assessment Report of the IPCC. Cambridge University Press. Cambridge, pp. 285-357.

Karas, J. (1997). Climate Change and the Mediterranean Region. Report prepared for Greenpeace. Greenpeace International, Amsterdam. 34 pp.

Klap, J.M. Oude Voshaar, J.H., de Vries, W., Erisman, J.W. (2000). Effects of environmental stress on forest crown condition in Europe. Part IV. Statistical analysis of relationships. Water, Air, \& Soil Pollution. 119, 387-420.

Kraxner, F., Nilson, S., Obersteiner, M. (2003). Negative emissions from BioEnergy use, carbon capture and sequestration (BECS) - the case of biomass production by sustainable forest management from semi-natural temperate forests. Biomass and Bioenergy 24, 285-296.

Kucharik, C.J., Norman, J.M., Gower, S.T. (1998). Measurements of branch and adjusting indirect leaf area index measurements. Agricultural and Forest Meteorology 91, 69-88.

Landscheidt, T., (2000). Solar wind near Earth: indicator of variations in global temperature. Proceedings of the $1^{\text {st }}$ Solar and Space weather Euroconference on the Solar Cycle and Terrestrial Climate, pp 497-500.

Lonsdale, G., Gibbs, J.N.(1996). Effects of climate change on fungal diseases of trees. In: Frankland, J.C., Magan, N., Gadd, G.M. editors. Fungi and environmental change. Cambridge, England: Cambridge University Press, 1-19.

Mossman, V.L.F. (2002). Anàlise especial e temporal das tendências das precipitações na Espanha Peninsular. Doctoral Thesis. 342 pp., in Portuguese.

Ninyerola M, Pons X y Roure JM. (2005). Atlas Climático Digital de la Península Ibérica. Metodología y aplicaciones en bioclimatología y geobotánica. ISBN 932860-8-7. Universidad Autónoma de Barcelona, Bellaterra.

Obersteiner, M., Azar, Ch., Kauppi, P., Möllersten, K., Moreira, J., Nilsson, S., Read, P.., Riahi, K., Schlamadinger, B., Yamagata, Y., Yan, J. and van Ypersele, J.P. (2001) Managing Climate Risk. Science; Volume 294, Number 5543, Issue of 26 Oct 2001, pp. 786-787.

Panel on Reconciling Temperature Observations (2000). Reconciling Observations of Global Temperature Change. Climate Research Committee, Board on Atmospheric Sciences and Climate, Commission on Geosciences, Environment and Resources, National Research Council, National Academy Press, $104 \mathrm{pp}$.

Parmesan, C., Yohe, G. (2003). A globally coherent fingerprint of climate change impacts across natural systems. Nature 421, 37-42.

Parry, M.L. (Ed.) (2000). Assessment of Potential Effects and adaptations for Climate Change in Europe: Summary and Conclusions. Jackson Environment Institute, University East Aglia, Norwich, UK. 24 pp.

Piervitali, E., Colacino, M., Conte, M., (1997). Signals of climatic change in the central-western Mediterranean basin. Theoretical \& Applied Climatology 58, 211-219.

Prieto, L., García Herrera, R., Díaz, J., Hernández, E., del Teso, T. (2004). Minimum extreme temperatures over Peninsular Spain. Global and Planetary Change 44, 59-71.

Schönwiese C.D., Rapp, J. (1997). Climate trend atlas of Europe based on observations, 1891-1990. Dordrecht, Netherlands Kluwer Academic Publishers; 1997. p. 228.

Soon, W., Baliunas, S., Posmentier, E.S., Okeke, P., (2000). Variations of solar coronal hole area and terrestrial lower tropospheric air temperature from 1979 to mid-1998: astronomical forcings of change in Earth's climate? New Astronomy 4 (8), 563-579.

Watson, R.T., Zinyowera, M., Moss, R.H., Dokken, D.J. (1997). The Regional Impacts of Climate Change: An Assessment of Vulnerability. Summary for Policymakers. IPCC Working Group II Special Report, 16 pp.

Wellburn, A. (1994). Air pollution and Climate Change, The Biological Impact. Longman Scientific \& Technical, Essex.

Zierl, B.(2002). Relations between crown condition and ozone and its dependence on environmental factors. Environmental pollution, 119. pp 55-68. 


\section{INFLUENCE OF CLIMATIC VARIABLES ON CROWN CONDITION}

Zierl, B.(2004). A simulation study to analyse the relations between crown condition and drought in Switzerland. Forest Ecology and Management, 188, pp 25-38. 